\title{
Article/Artigo
}

\section{Viral etiology among the elderly presenting acute respiratory infection during the influenza season}

\author{
Etiologia viral de infecção respiratória aguda entre idosos, durante a temporada de gripe
}

Aripuanã Sakurada Aranha Watanabe ${ }^{1}$,Emerson Carraro ${ }^{1}$, João Manuelo Grisi Candeias ${ }^{2}$, Maria Rita Donalísio ${ }^{3}$, Élcio Leal ${ }^{4}$, Celso Francisco Hernandes Granato ${ }^{1}$ and Nancy Bellei ${ }^{1}$

\begin{abstract}
Introduction: Acute respiratory tract infections are the most common illness in all individuals. Rhinoviruses have been reported as the etiology of more than $50 \%$ of respiratory tract infections worldwide. The study prospectively evaluated 47 elderly individuals from a group of 384 randomly assigned for acute respiratory viral infections (cold or flu) and assessed the occurrence of human rhinovirus (HRV), influenza A and B, respiratory syncytial virus and metapneumovirus (hMPV) in Botucatu, State of São Paulo, Brazil. Methods: Forty-nine nasal swabs collected from 47 elderly individuals following inclusion visits from 2002 to 2003 were tested by GenScan RT-PCR. HRV-positive samples were sequenced for phylogenetic analysis. Results: No sample was positive for influenza A/B or RSV. HRV was detected in $28.6 \%(14 / 47)$ and hMPV in $2 \%(1 / 47)$. Of 14 positive samples, 9 isolates were successfully sequenced, showing the follow group distribution: 6 group A, 1 group B and 2 group C HRVs. Conclusions: The high incidence of HRV during the months of the influenza season requires further study regarding HRV infection impact on respiratory complications among this population. Infection caused by $\mathrm{HRV}$ is very frequent and may contribute to increasing the already high demand for healthcare during the influenza season.
\end{abstract}

Keywords: Respiratory viruses. Human rhinovirus. Genescan RT-PCR. Reverse transcription polymerase chain reaction. Elderly.

\section{RESUMO \\ Introdução: Infecções agudas do trato respiratório estão entre as doenças mais comuns em todas as pessoas. Os rinovírus têm sido descritos como agente etiológico de mais de $50 \%$ das infecções do trato respiratório ao redor do mundo. $\mathrm{O}$ objetivo deste trabalho foi avaliar a ocorrência de rinovírus humano (HRV), influenza vírus $\mathrm{A}$ e $\mathrm{B}$, vírus respiratório sincicial humano e metapneumovírus (hMPV) em uma população de idosos que apresentava sintomas de gripe ou resfriado, e que residiam na Cidade de Botucatu, Estado de São Paulo, Brasil. Métodos: Foram coletados swabs nasais de 47 idosos após visitas de inclusão, entre os anos de 2002 e 2003 e que foram testadas através de GeneScan RT-PCR. Resultados: HRV foi detectado em 28.6\% (14/47) e hMPV em 2\% (1/47). De 14 amostras positivas para HRV, 9 foram sequenciadas, mostrando a seguinte distribuição de grupos: grupo A: 6 amostras, grupo B: 1 amostra e grupo C: 2 amostras. Conclusões: A alta incidência de HRV durante os meses de ocorrência de gripe necessita de estudos posteriores para avaliar o impacto desse vírus entre os idosos. A alta frequência de HRV pode contribuir para o aumento da demanda por serviços de saúde durante a estação de influenza.}

Palavras-chaves: Viroses respiratórias. Rinovírus humano. Genescan RT-PCR. Reação em cadeia da polimerase. Idosos.

1. Clinical Virology Laboratory, Infectious Diseases Unit, Medicine Department, São Paulo Federal University, Sao Paulo, Brazil. 2. Human and Animal Virology Laboratory, Biosciences Institute, São Paulo State University, Botucatu, SP, Brazil. 3. Medical Sciences College, Campinas State University, Campinas, SP, Brazil. 4. Institute of Biotechnology, Federal University of Pará, Brazil.

Address to: Dr. Aripuanã Sakurada Aranha Watanabe. Lab. Virologia Clínica/DIPA/DM/UNIFESP. R. Pedro de Toledo $781 / 15^{\circ}$ andar, 04039-032 São Paulo, SP, Brazil.

Phone: 5511 5081-5394; Fax: 5511 5081-5394

e-mail: watanabe@unifesp.br

Received in $01 / 12 / 2009$

Accepted in 18/10/2010

\section{INTRODUCTION}

The elderly show increased susceptibility to respiratory infections and related complications ${ }^{1}$. On average, community-dwelling elderly individuals suffer from 1.2 to 1.6 acute respiratory infections per year ${ }^{2,3}$. The role of influenza virus in severe disease among the elderly population is well described throughout the world. Until recently, the possible contribution of respiratory viruses other than influenza has attracted little attention and has probably been underestimated. Some studies indicate that respiratory syncytial virus (RSV) and human metapneumovirus (hMPV) have a greater role in respiratory tract infections of the elderly $y^{4,5}$ and a recently paper from Louie et $\mathrm{al}^{6}$ described an association between high mortality and an outbreak of human rhinovirus (HRV) in a long-term care facility for elderly individuals. Indeed, laboratory diagnosis of acute respiratory infections (ARI) in symptomatic elderly individuals has focused almost exclusively on institutionalized elderly individuals $\mathrm{s}^{7.9}$ and patients seeking medical consultation ${ }^{10,11}$. Thus, remarkably little is known regarding respiratory viral infections among the elderly living in the community ${ }^{2}$.

Such studies have shown that rhinoviruses cause the great majority of these respiratory illnesses. Advances in diagnostic techniques have enabled more complete identification of the viruses involved in respiratory infections ${ }^{12}$.

In Brazil, the National Influenza Immunization Program has included the elderly since 1995 and influenza surveillance has been systematic established recently but no data are available regarding the presence of other respiratory pathogens in community-dwelling elderly individuals in Brazil $^{13}$.

The purpose of this study was to evaluate the occurrence of human rhinovirus, influenza A and B, respiratory syncytial virus and metapneumovirus among the elderly population presenting flu or cold symptoms in Botucatu, State of São Paulo, Brazil. 


\section{METHODS}

\section{Subjects}

In a previous study ${ }^{14}, 384$ elderly were followed during the winter months to evaluate the appearance of respiratory acute symptoms. This study was conducted using a systematic random sample ( $n=384$ ) of the elderly population of the urban area of Botucatu, a city of 130 thousand inhabitants in the central-western region of the State of São Paulo. The initial choice of the samples was based on a registry of 9,000 families for a population-based study of work accidents in the municipality ${ }^{14}$. Criteria for the inclusion of randomly selected subjects in the study were as follows: age 60 years-old or over, living in Botucatu, at home during one of the three attempted home visits, not institutionalized and agreeing to participate in the survey by providing written informed consent. Of the total number of individuals, 365 were interviewed and 47 patients contacted the research group reporting acute respiratory symptoms; a nasal swab was collected in a subsequent visit. Forty-nine nasal swabs from 47 symptomatic elderly individuals, presenting symptoms for up to 7 days, who participated in household survey study and who contacted the group after the inclusion visits, were collected during years of 2002 and 2003 for the virological study. A questionnaire was also completed to obtain demographic and clinical data and evaluate the immunization status of the individuals.

Clinical specimens were processed and separated in two aliquots: one for molecular methods (Influenza A/B, RSV, hMPV and HRV) and other for viral isolation (influenza $\mathrm{A} / \mathrm{B}$ and RSV).

\section{Viral isolation}

All specimens were processed on the day of their collection and treated with antibiotics. One hundred microliters were inoculated into 2 monolayer wells each of Hep-2 and MDCK cells cultured in 24well polystyrene microplates (Corning, New York, NY). All cultures were incubated at $37^{\circ} \mathrm{C}$ and examined every day for the cytopathic effect (CPE) over a period of 12 days. Two blind cell passages were performed independent of the appearance of the CPE. The presence of respiratory viruses was suggested by CPE. Independent of the presence or absence of CPE, all medium passages were collected for nucleic acid extraction and subsequent GeneScan analysis.

\section{Nucleic acid extraction}

Aliquots $(250 \mu \mathrm{l})$ of each specimen and medium supernadant cell culture were dispensed into a tube, each containing $750 \mu \mathrm{l}$ of Trizol-LS (Invitrogen, Carlsbad, CA) and frozen at $-70^{\circ} \mathrm{C}$ until their extraction. Total RNA/DNA extraction by Trizol was performed in accordance with the manufacturer's instructions. Nucleic acid extracts were diluted with $50 \mu \mathrm{l}$ of ultrapure nuclease free water (Invitrogen, Carlsbad, CA) containing RNAse inhibitor (RNAguard; Applied Biosystems, Foster City, CA) at a final concentration of $1 \mathrm{U} / \mu \mathrm{l}$. Extracts were transcribed into cDNA immediately or stored at $-70^{\circ} \mathrm{C}$. Reverse transcription was performed using SuperScript III Transcriptase Reverse (Invitrogen, Carlsbad, CA) and random primers (Invitrogen, Carlsbad, CA).

GeneScan for influenza $A / B$, human respiratory syncytial virus and human metapneumovirus

The RT-PCR GeneScan method for influenza A and B, respiratory syncytial virus and metapneumovirus was performed as described elsewhere ${ }^{15}$. This technique uses a positive strand primer 5 '-end- labeled with fluorescent6-carboxyfluorescein (6-FAM). Following RT-PCR, amplified products of each specimen were pooled and purified by precipitation with ethanol to remove the excess salt. Amplicon analysis was then performed on an ABI Prism 310 Genetic Analyzer (Applied Biosystems) with GeneScan software (version3.1.2), using a $47 \mathrm{~cm}$ capillary with POP-4 ${ }^{\mathrm{TM}}$ polymer. Electropherograms were examined and specimens showing discrete amplicon peaks within $\leq 1$ nucleotides of the respective positive control peak were considered positive.

\section{RT-PCR for human rhinovirus}

RT-PCR for HRV was performed as described elsewhere ${ }^{16}$, with minor modifications. The eluted RNA was transcribed into cDNA with Moloney Murine Reverse Transcriptase (MMLV-RT; Invitrogen, Carlsbad, CA) and virus specific oligonucleotide primer, for $1 \mathrm{~h}$ at $37^{\circ} \mathrm{C}$. Following MMLV-RT denaturation at $70^{\circ} \mathrm{C}$, virusspecific oligonucleotide primer and Platinum Taq DNA Polymerase (Invitrogen, Carlsbad, CA) were added and 40 cycles of PCR were run, consisting of denaturation $\left(45 \mathrm{sec}\right.$ at $\left.95^{\circ} \mathrm{C}\right)$, annealing $(45$ sec at $61^{\circ} \mathrm{C}$ ) and DNA extension $\left(1 \mathrm{~min}\right.$ at $\left.72^{\circ} \mathrm{C}\right)$. RT-PCR targets the hypervariable part of the $5^{\prime} \mathrm{NCR}$, the entire VP4 gene and the 5' terminus of the VP2 gene. RT-PCR was standardized with sensitivity of $10^{-3,25} \mathrm{TCID}_{50} / 100 \mu \mathrm{L}$. The presence of PCR products was visualized by agarose gel electrophoresis according to their $549 \mathrm{bp}$ molecular weight. Positive (HRV 39) and negative water controls were tested in all reactions.

\section{Purification and sequencing of human rhinovirus PCR products}

The PCR products were purified using a ChargeSwitch PCR Clean-Up Kit (Invitrogen, Carlsbad, CA) and sequenced in both directions using the Sanger dideoxy cycle-sequencing method with the ABI Prism BigDye Terminator Cycle Sequencing Ready Reaction Kit, in accordance with the manufacturer's instructions, using the 3130XL Genetic Analyzer (Applied Biosystems, Foster City, CA).

\section{Sequence alignment and phylogenetic analyses}

Multiple sequences were aligned using Clustal X (v2.0.11). The multiple-sequence alignment was subjected to phylogenetic analyses using the program TOPALi (v2.5). Phylogenetic relationships were assessed using neighbor-joining, maximum-parsimony and maximum-likelihood methods. Forty-nine published HRV sequences within the VP4-VP2 were obtained from the GenBank database (NCBI) and used as reference.

\section{Ethical considerations}

This study was approved by the Research Ethics Committee of Botucatu Medical School according to resolution no. OF. 42/2006 $\mathrm{CEP}$ and written consent was obtained from all elderly individuals.

\section{RESULTS}

Overall influenza immunization coverage in this recruited population $(\mathrm{n}=365)$ was $62.3 \%$. In the 47 symptomatic elderly individuals, patients that contacted the research group, age ranged from 60 to 85 years-old, with a median age of 69 years-old and a mean age 70 yearsold ( \pm 7.16 years). The proportion of males and females was $29.8 \%$ and $70.2 \%$, respectively. Coryza, sore throat and cough were common symptoms (69\%, 62.1\% and 51.7\% respectively; $\mathrm{n}=29$ ); however, no clinical information was available for 18 patients. The vaccine rate in 2002 was $66.7 \%$ among this patients ( $\mathrm{n}=39$ with information). 


\section{Viral detection}

Of the 49 samples tested by different molecular assays 15 (30.6\%) were positive: rhinovirus was detected in $14(28.6 \%)$ samples and hMPV in one (2\%) sample. None of the samples were positive for influenza A/B or RSV by the GeneScan assay or cell culture. Regarding HRV infections, 9/14 (64.3\%) occurred during the influenza season: in five cases, samples were collected during winter months, 4 in the autumn, 4 in summer months and 1 during spring. Figure 1 shows the samples collected and positive cases over the study period.

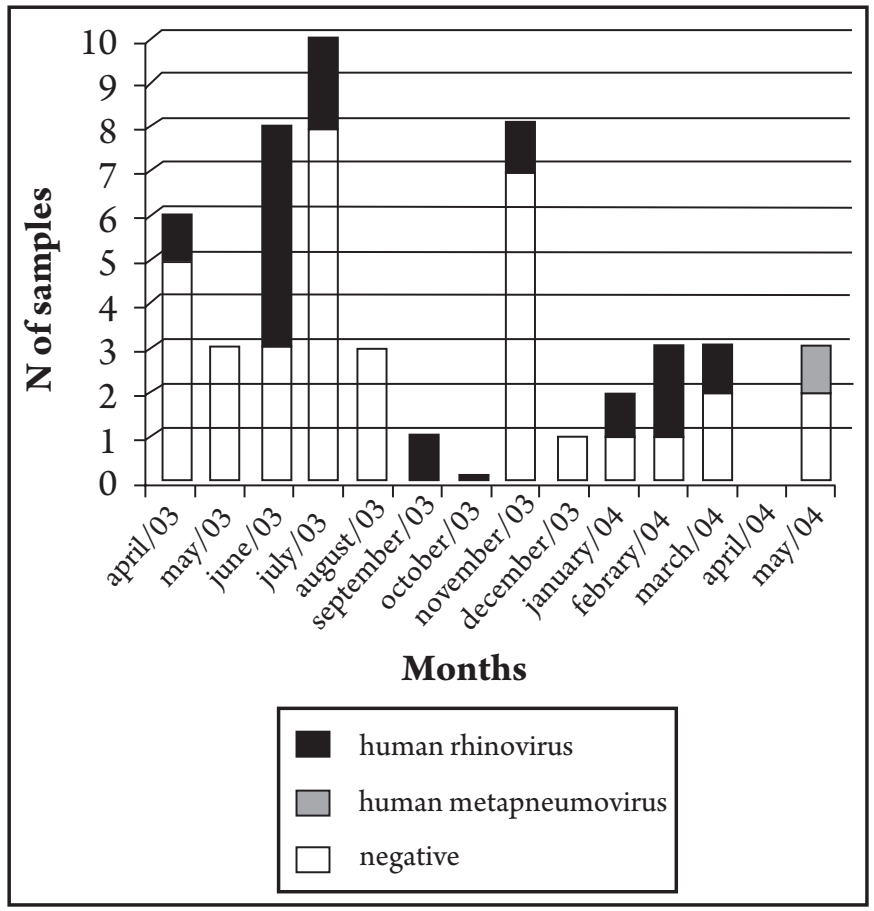

FIGURE 1 - Samples collected and positive cases during the study period.

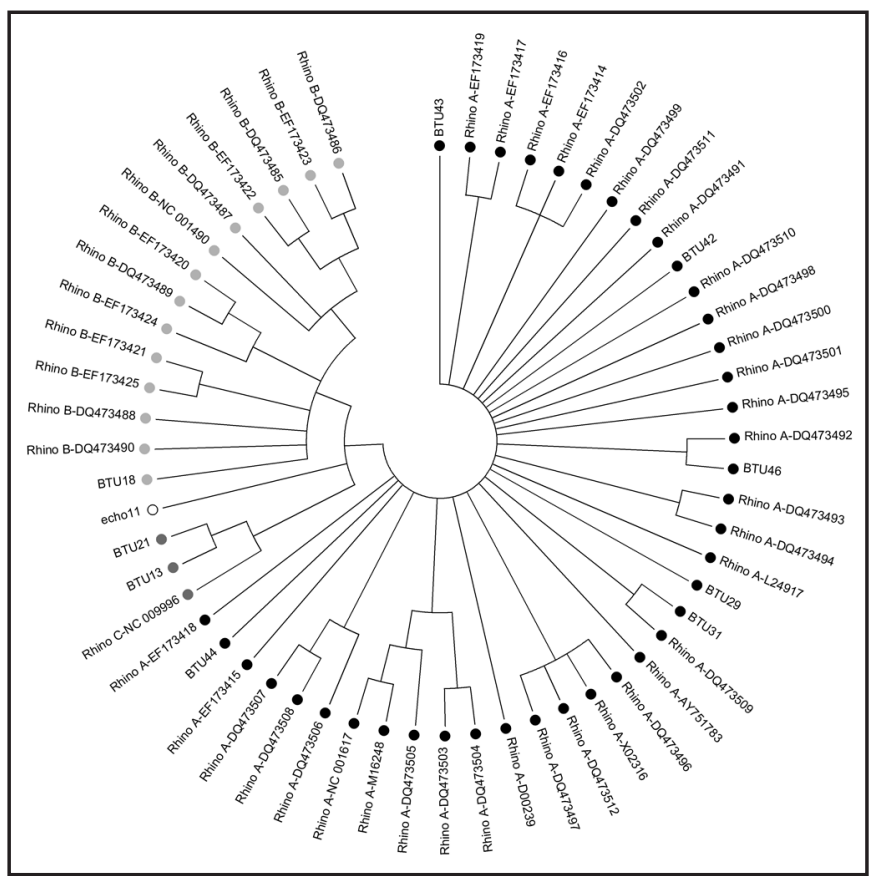

FIGURE 2 - A neighbor-joining phylogenetic tree analysis of the VP4/VP2 region of $9 \mathrm{HRV}$ strains from Botucatu, State of São Paulo, Brazil and 48 prototype HRV group from GenBank (access number follow abbreviations Rhino A, B and C) showing their grouping into three HRV species: $\bullet=H R V-A, \bullet=H R V-B$, $\bullet=$ HRV-C, $\mathrm{O}=$ outgroup (echo 11).

\section{Phylogenetic analysis of clinical HRV isolates}

To evaluate the ability of the assay to genotype HRVs, a total of 14 unknown clinical respiratory isolates were sequenced. Nine isolates were successfully sequenced and identified. A total of $6(66 \%)$ HRVs were identified for group A, 1 for group B (11\%) and 2 (22\%) for group C. Figure 2 depicts the maximum likelihood tree showing the pattern of distribution of Brazilian isolates into three main clusters, representing the HRV species A, B, and C. To strengthen this analysis, homologous sequences of the main HRV species isolates were used as species references (the GenBank identities of these references are shown in the tree) (Figure 2).

\section{DISCUSSION}

This first study assessing viral etiologies among symptomatic elderly individuals in the influenza immunized community in Brazil verified $30 \%$ viral detection by different molecular assays. Donalísio et $\mathrm{a}^{14}$ described a vaccine coverage of $63.2 \%$ in elderly individuals from Botucatu, SP, Brazil in 2002. A total of 384 individuals were initially recruited from a databank of 9,000 family, but only $47(12.4 \%)$ contacted the research team following the inclusion visit. The individuals selected $(n=384)$ are likely to be representative of the elderly population in the region, despite the low number of samples collected.

In the present study, HRV was the most frequently detected agent. HRV infections are common among patients, including the elderly, and account for 25 to $50 \%$ of respiratory illnesses among community-dwelling elderly individuals ${ }^{2}$. Few reports exist in Brazil regarding rhinovirus respiratory infections. In a recent study, the authors verified that HRV infections were very frequent in the Brazilian adult population, resulting in more severe presentation that the common cold. Bellei et $\mathrm{al}^{17}$ reported that approximately $50 \%$ of HRV-infected individuals presented influenza-like illness and that it was circulating in the same period as influenza.

Complications due to HRV infection seem to be more frequent in the elderly, particularly in home care services. In two studies conducted at nursing homes and long-term care facilities for the elderly, outbreaks were described with mortality rates varying of 6 to $21 \%$. In both studies, the deaths were directly attributed to acute infection caused by $\mathrm{HRV}^{6,18}$.

HRV phylogenetic analyses show a distribution of groups coherent with the literature. An interesting fact was observed regarding HRV C. The first study describing this new HRV group was conducted in mid $2006^{19}$. Thus, it was very surprising that HRV $\mathrm{C}$ was detected infecting a patient as early as 2003 . This original data supports the hypothesis that this new group had been already circulating before the study by Lamson et $\mathrm{al}^{19}$.

Falsey et $\mathrm{al}^{5}$ described a frequency of $1.7 \%$ for hMPV infection in symptomatic elderly individuals. In this study, a frequency of $2 \%$ was determined, in agreement with the literature.

Influenza and RSV usually cause complications in the elderly population, but in this study, neither of them were detected. The sensitivity of GeneScan RT-PCR for Influenza virus, RSV and hMPV is very high, described by Erdman et al as a sensitive and specific method for viral detection ${ }^{20}$. During 2002 and 2003, low activity of influenza virus in the elderly population in the community was described in the city of São Paulo, Brazil ${ }^{21}$. High influenza immunization adherence and variability in activity of the RSV pattern $^{22}$ are implicated in the current data. RSV activity can be 
variable over several years and this variation is well documented in the worldwide literature ${ }^{22-24}$.

Based on data obtained in the present study, infection caused by $\mathrm{HRV}$ is very frequent and may contribute to increasing the already high demand for healthcare during the influenza season. Analysis of viral etiology among this immunized elderly population showed that HRV was the main agent responsible for healthcare demands. The high incidence of HRV during the months of the influenza season requires further investigation regarding the impact of $\mathrm{HRV}$ infection on respiratory complications in this population.

\section{ACKNOWLEDGMENTS}

The authors are grateful to Dr Eurico Arruda Neto, Faculdade de Medicina de Ribeirão Preto, Universidade de São Paulo, Brazil, for providing HRV 39 isolate used as positive control for HRV RT-PCR and to Dr Edison Luiz Durigon and Luciano Thomazelli, Instituto de Ciências Biológicas, Universidade de São Paulo, Brazil, for providing equipment and important contributions.

\section{CONFLICT OF INTEREST}

The authors declare that there are no conflicts of interest.

\section{FINANCIAL SUPPORT}

FAPESP, CNPq, CAPES. ASA Watanabe was sponsored by the CNPq.

\section{REFERENCES}

1. Miller RA. The aging immune system: primer and prospectus. Science 1996; 273:70-74.

2. Nicholson KG, Kent J, Hammersley V, Cancio E. Acute viral infections of upper respiratory tract in elderly people living in the community: comparative, prospective, population based study of disease burden. BMJ 1997; 315: 1060-1064.

3. Graat JM, Schouten EG, Kok FJ. Effect of daily vitamin E and multivitaminmineral supplementation on acute respiratory tract infections in elderly persons: a randomized controlled trial. JAMA 2002; 288:715-721.

4. Falsey AR, Walsh EE. Viral Pneumonia in Older Adults. Clin Infec Dis 2006; 42:518-524.

5. Falsey AR, Erdman D, Anderson LJ, Walsh EE. Human metapneumovirus infections in young and elderly adults. J Infect Dis 2003; 187:785-790.

6. Louie JK, Yagi S, Nelson FA, Kiang D, Glaser CA, Rosenberg J, et al. Rhinovirus outbreak in a long term care facility for elderly persons associated with unusually high mortality. Clin Infect Dis 2005; 41:262-265.

7. Chernoff R. Meeting the nutritional needs of the elderly in the institutional setting. Nutr Rev 1994; 52:132-136.

8. Drinka PJ, Gravenstein S, Krause P, Langer EH, Barthels L, Dissing M, et al. Non-influenza respiratory viruses may overlap and obscure influenza activity. J Am Geriatr Soc 1999; 47:1087-1093.

9. Falsey AR, McCann RM, Hall WJ, Tanner MA, Criddle MM, Formica MA, et al. Acute respiratory tract infection in daycare centers for older persons. J Am Geriatr Soc 1995; 43:30-36.

10. Macfarlane JT, Colville A, Guion A, Macfarlane RM, Rose DH. Prospective study of aetiology and outcome of adult lower respiratory tract infections in the community. Lancet 1993; 341:511-514.

11. Carrat F, Tachet A, Rouzioux C, Housset B, Valleron AJ. Evaluation of clinical case definitions of influenza: detailed investigation of patients during the 1995-1996 epidemic in France. Clin Infect Dis 1999; 28:283-290.
12. Monto AS. Epidemiology of Viral Respiratory Infections. Am J Med 2002; 112:4S-12S

13. Francisco PMSB, Donalisio MRC, Latorre MRDO. Tendência da mortalidade por doenças respiratórias em idosos do Estado de São Paulo, 1980 a 1998. Rev Saude Publica 2003; 37:191-196.

14. Donalisio MR, Ruiz T, Cordeiro R. Factors associated with influenza vaccination among elderly persons in Southeastern Brazil. Rev Saude Publica 2006; 40:1-5.

15. Thomazelli LM, Vieira S, Leal AL, Sousa TS, Oliveira DB, Golono MA, et al Surveillance of eight respiratory viruses in clinical samples of pediatric patients in southeast Brazil. J Pediatr 2007; 83:422-428.

16. Savolainen C, Mulders MN, Hovi T. Phylogenetic analysis of rhinovirus isolates collected during successive epidemic seasons. Virus Res 2002; 85:41-46.

17. Bellei N, Carraro E, Perosa A, Watanabe A, Arruda E, Granato C. Acute respiratory infection and influenza-like illness viral etiologies in Brazilian adults. J Med Virol 2008; 80:1824-1827.

18. Hicks LA, Shepard CW, Britz PH, Erdman DD, Fischer M, Flannery BL, et al Two outbreaks of severe respiratory disease in nursing homes associated with rhinovirus. J Am Geriatr Soc 2006; 54:284-289.

19. Lamson D, Renwick N, Kapoor V, Liu Z, Palacios G, Ju J, et al. MassTag polymerase- chain-reaction detection of respiratory pathogens, including a new rhinovirus genotype, that caused influenza-like illness in New York State during 2004-2005. J Infect Dis 2006; 194:1398-402.

20. Erdman DD, Weinberg GA, Edwards KM, Walker FJ, Anderson BC, Winter J, et al. GeneScan reverse transcription-PCR assay for detection of six common respiratory viruses in young children hospitalized with acute respiratory illness. J Clin Microbiol 2003; 41: 4298-4303.

21. Bellei NC, Carraro E, Castelo A, Granato CF. Risk factors for poor immune response to influenza vaccination in elderly people. Braz J Infect Dis 2006; 10:269-273.

22. Vieira SE, Stewien KE, Queiroz DA, Durigon EL, Török TJ, Anderson LJ, et al. Clinical patterns and seasonal trends in respiratory syncytial virus hospitalizations in São Paulo, Brazil. Rev Inst Med Trop Sao Paulo 2001; 43:125-131.

23. Viegas M, Barrero PR, Maffey AF, Mistchenko AS. Respiratory viruses seasonality in children under five years of age in Buenos Aires, Argentina: a fiveyear analysis. J Infect 2004; 49:222-228.

24. Rafiefard F, Johansson B, Tecle T, Orvell C. Molecular epidemiology of respiratory syncytial virus (RSV) of group A in Stockholm, Sweden, between 1965 and 2003 Virus Res 2004; 105:137-145. 